\title{
Approach for Reclamation and Improving Fertility of Saline-Sodic Soils
}

\author{
M. K. Abdel-Fattah and A. M. A. Merwad
}

Soil Science Department, Faculty of Agriculture, Zagazig

University, Egypt

\begin{abstract}
A
POT experiment was conducted under the greenhouse conditions at the Farm of the Faculty of Agriculture, Zagazig University to try reclamation and cultivation of saline-sodic soils. Soil samples were collected from Sahl El-Tin, Sinai Governorate, Egypt. Plastic pots were filled with soil. Soil was treated with compost or gypsum as soil amendments before filling. The gypsum and compost addition rate were 10.32 and $20 \mathrm{Mg} \mathrm{ha}^{-1}$, respectively. The soils were leached with water having EC $1.2 \mathrm{dSm}^{-1}$ using intermittent method. Reclamation requirements (RR) were calculated based on pore volume (PV). Soil was leached with amount of water equivalent 1.5 PV (1.5 PV was equal 4.85 liter of water). Leaching water amount was divided into 10 equal quantities each one equal 0.49 liter. Following termination of leaching, samples were taken from soils were amended with gypsum and compost and analyzed. After reclamation process, the same pots were planted with wheat (Triticum aestivum cv. Sakha 93) to study the effect of fulvic acid "FA" as application soil and foliar sprays with Moringa leaf extract "MLE" and Marine algae extract "MAE" as Ascophyllum nodosum (Phaeophyceae) on photosynthetic pigments, yield and nutrient uptake of wheat (Triticum aestivum cv., Sakha 93) under newly reclaimed soils with gypsum and compost. The results of the study indicated that gypsum and compost showed a pronounced decreased in bulk density, EC, pH, SAR and ESP compared with the initial soil with superiority of gypsum on compost in reducing EC, SAR and ESP. The highest values of plant height, leaf area, chlorophyll a, b and caroteniods, yield, straw and grain NPKuptake, 1000 grain weight and protein content were obtained with FA combined with moringa extract spray. However, non-treated plants showed the lowest one. Spraying with moringa leaf extract gave a significant increase in growth yield parameters; yield, photosynthetic pigments, NPK-uptake, 1000 grain weight and protein content compared to foliar spray with marine algae extract in the two soils. Soils reclaimed with compost gave higher values of yield, straw and grains NPK- uptake and protein content than the values under application of gypsum under different treatments.
\end{abstract}

Keywords: Saline, Sodic, Gypsum, Compost, Wheat, Fluvic acid Moringa leaf extract, Marine algae extract, Newly reclaimed soils 
Salt-affected soils occupy wide regions scattered all over the world, particularly in arid and semi-arid climates. Agriculture in Egypt, as in many other countries in the arid and semi-arid regions, is suffering from salinity hazards. While the cultivated area is only 7.2 million feddans, the area of salt-affected soils has been estimated to be about 1.9 millions feddans. Most of these areas are located in the northern and eastern of the Nile Delta as well as patches in Valley and along the two Nile branches. Irrigated agriculture in arid and semi-arid regions of the world has resulted in salinity and water logging problems that are threatening the sustainability of our lands (Chhabra, 1996).

Mashali (1991) classified the management practices of salt-affected soils are (i) hydraulic management including leaching, irrigation, and drainage; (ii) physical involving, tillage, land preparation, and sanding, (iii) chemical including amendments, conditioners, and fertilizer; and (iv) biological including crop rotation and pattern. The kind and amount of chemical amendments to be used for reclamation of saline sodic and non-saline sodic soils are based on several factors. Among them are the followings: physical and chemical properties of the soil, the time available for reclamation, the final required level of exchangeable sodium percent (ESP) and the cost of reclamation amendments and water application.

Abdel-Moez and Saleh (1999) found that the organic materials have different effects on modifications of the physical and chemical properties of soils as well as their influence of their nutrition status and soil fertility. Incorporation of plant residues sustains organic matter in soil, enhances biological activity and improves soil physical properties (Kumar and Goh, 2000; Palm et al., 2001).In addition, compost is a rich source of organic matter which plays an important role in sustaining soil fertility and hence in sustainable agricultural production. In addition to being a source of plant nutrient, it improves the physicochemical and biological properties of the soil. As a result of these improvements, the soil: (i) becomes more resistant to stresses such as drought, diseases and toxicity; (ii) helps the crop in improved uptake of plant nutrients; and (iii) possesses an active nutrient cycling capacity because of vigorous microbial activity.

Many beneficial effects are attributed to foliar application of fulvic acid (FA), including stimulation of plant metabolism, increased enzyme activity (transaminase, invertase), increased bioavailability and uptake of nutrients (Jifon and Lester, 2009), and increased crop growth and yield (Priya et al., 2011).Fulvic acid has maximum influence on chemical reactions because of the presence of more electronegative oxygen atoms than any other humate molecules, which enhances membrane permeability( Priya et al.,2014).

Moringa leaves have been reported to be a rich source of $\beta$-carotene, protein, vitamin $C$, calcium and potassium and act as a good source of natural antioxidants such as ascorbic acid, flavonoid, phenolics and carotenoids

Egypt. J. Soil Sci. 56, No. 4(2016) 
(Dillard and German, 2000; Siddhuraju and Becker, 2003). In addition, moringa leaf is also rich in ascorbates, carotenoids, phenols, potassium and calcium, which have plant growth-promoting capabilities and often applied as exogenous plant growth enhancers (Foidl et al., 2001). Antioxidants such as ascorbic acid and glutathione, which are found at high concentrations in moringa chloroplasts and other cellular compartments, are crucial for plant defense against oxidative stress (Noctor and Foyer, 1998). Merwad (2015) showed that the aqueous and ethanolic leaf Moringa extracts at rate of $3 \%$ increase growth, yield, photosynthetic and nutrient uptake $(\mathrm{N}, \mathrm{P}, \mathrm{K}, \mathrm{Ca}, \mathrm{Mg}$ and $\mathrm{Fe}$ ) of spinach plants. Siddhuraju and Becker (2003) observed antioxidant properties in the solvent extract of moringa leaves and reported that leaves are potential source of natural antioxidants.

Seaweed extracts have been used for decades in agriculture and horticulture as biostimulants to promote plant growth and increase crop yields. When applied in small amounts, the beneficial effects of seaweed extracts on crop growth have been attributed to plant growth regulators, and possibly micronutrients, that stimulate root growth, mineral uptake, photosynthetic capacity, and stress tolerance (Khan et al. 2009). Under conditions of water stress, only few studies have provided evidence of improved plant performance upon treatment with seaweed extracts (Khan et al., 2012;Zhang and Ervin 2004). Anti-stress effects may be related to bioactive chemicals contained in the extracts and increased antioxidant enzyme activity (Fike et al., 2001), but their physiological mechanism of action is largely unknown. In some studies, seaweed extracts from Ecklonia maxima increased yields under adequate nutrient supply (Mooney and van Staden 1985), thereby demonstrating a capacity to enhance the effectiveness of conventional fertilizers. In contrast, other studies indicated that extracts from the same seaweed species increased yield only in nutrient-stressed wheat (Beckett et al., 1994) or even in the absence of mineral fertilizer (Nelson and van Staden 1986). Recently, Khan et al. (2011) demonstrated that the extract of different seaweed species, Ascophyllum nodosum, induced cytokinin-like activity in Arabidopsis thaliana when applied as a liquid culture or foliar spray.The use of balanced nutrient solutions in the above studies did not allow the investigation of seaweed extract effects on specific nutrient deficiencies. Beckett and van Staden (1990) reported beneficial seaweed extract effects on K-stressed wheat, and Papenfus et al. (2013) detected improved growth of okra seedlings under $\mathrm{K}$ or $\mathrm{P}$, but not under $\mathrm{N}$, deficiency. Nitrogen, along with water, is a major limiting and economic factor in crop production that is also associated with environmental degradation resulting from excessive or untimely fertilizer application. Draught stress and $\mathrm{N}$ deficiency are constraining winter wheat production and yield stability under rained conditions worldwide (Shangguan et al., 2000).

The aim of the present work is to study the effect of fluvic acid applied through the soil and moringa leaf and marine algae extracts applied as foliar 
spray on photosynthetic pigments, yield and nutrient uptake of wheat under newly reclaimed soils with compost and gypsum.

\section{Materials and Methods}

A pot experiment was conducted under the greenhouse conditions at the Farm of the Faculty of Agriculture Zagazig University to try reclamation and cultivation of salt affected soils. Soil samples were collected from Sahl El-Tin, Sinai Governorate, Egypt, which is affected by salinization and sodification. They were air dried, crushed and sieved through a 2-mm sieve and analyzed for their physicochemical characteristics (Table 1). Thirty-six of plastic pots of internal dimensions $20 \times 25 \mathrm{~cm}$ were filled with $10 \mathrm{~kg}$ soil. Soil was treated with compost or gypsum before filling the pots with soil. Gypsum requirements (GR) were calculated to reduce the initial ESP from 19.61 to $10 \%$ for $30-\mathrm{cm}$ soil according to USDA (1954). The gypsum was of $97 \%$ purity and its addition rate was 10.32 Mgha-1. Concerning compost addition rate was $20 \mathrm{Mg}$ ha-1 and the characteristics of compost are shown in Table 2. After mixing amendments with soil matrix, the soils were leached with water having EC 1.2 dSm-1. Leaching was done using intermittent method so as to add portions to the already saturated soil; and obtain leachates equal to the added portions. Reclamation requirements (RR) were calculated based on pore volume. Pore volume (PV) is amount of water that fill all pore spaces and soil reach to the state of saturation. Soil was leached with amount of water equivalent 1.5 PV (1.5 PV was equal 4.85 liter of water). Leaching water amount was divided into 10 equal quantities each one equal 0.49 liter. Following termination of leaching, samples were taken from soil were amended with gypsum and compost. Soil samples were air dried, crushed, sieved through a 2-mm sieve and analysis according to USDA (1954). Results included in Table 1 as average value.

Following termination of reclamation process, the same pots were planted with wheat (Triticum aestivum cv. Sakha 93) to evaluate the effect of fulvic acid "FA" as application soil and foliar sprays with Moringa leaf extract "MLE" and Marine algae extract "MAE" as Ascophyllum nodosum (Phaeophyceae) on yield and nutrient uptake of wheat under of newly reclaimed soil.

All pots were supplied with the recommended doses of N, P and K. Nitrogen was added in 3 equal splits as ammonium sulfate $(210 \mathrm{~g} \mathrm{~N} \mathrm{kg-1})$ at a rate of 120 $\mathrm{kg} \mathrm{N}$ ha-1, the first was before the 1st irrigation while the second and third splits were added after 40 and 70 days, respectively from the first splits. $\mathrm{P}$ and $\mathrm{K}$ fertilizers were added to the soil as ordinary super phosphate $(65.5 \mathrm{~g} \mathrm{P} \mathrm{kg-1})$ at a rate of $31 \mathrm{~kg} \mathrm{P}$ ha-1 and potassium sulphate $(410 \mathrm{~g} \mathrm{~K} \mathrm{~kg}-1)$ at a rate of $50 \mathrm{~kg} \mathrm{~K}$ per ha-1 during soil preparation. Fulvic acid was applied through the soil at a rate of $3 \mathrm{~kg}$ ha- 1 .

An amount of $20 \mathrm{~g}$ of young Moringa oleifera leaves was mixed with $675 \mathrm{ml}$ of $80 \%$ ethanol as suggested by Makkar and Becker (1996). The suspension was stirred using a homogenizer to help maximize the amount of the extract. The

Egypt. J. Soil Sci. 56, No. 4(2016) 
solution was filtered using No.2 whatman filter paper. The extract of Moringa oleifera leaves were used within five hours from cutting and extracting (if not ready to be used,the extract or the solution prepared was stored at $0^{\circ} \mathrm{C}$ and only taken out when needed for use). The chemical composition of Moringa oleifera leave extract were investigated using (Fuglie, 2000 and Moyo et al., 2011) are represented in Table 3. Foliar spraying of extract were done three equal doses at 30,45 and 60 days after planting at a rate of $3 \%(30 \mathrm{ml} \mathrm{L}-1)$. Foliar spraying of marine algae extract as Ascophyllum nodosum (Phaeophyceae) were done three equal doses at a rate of $0.5 \mathrm{ml} \mathrm{L}-1$ at the same time of spraying moringa extract. The chemical composition of marine algae extract were investigated are represented in Table 4.

The experiment includes different combinations of the former treatments as follows: Control, FA, MAE, MLE, FA+MAE, FA+MLE. Previous treatments were executed on the reclaimed soil by gypsum and at other times on the reclaimed soil by compost. The design was a factorial randomized complete block with three replicates. A random sample of three plants was taken from each treatment at 75 days old (booting stage) to record plant vegetative characters (Plant height and leaf area) and photosynthetic pigments (chlorophyll a, b and caroteniods) were determined spectrophotometrically (Metzner et al., 1965).

At harvest, plant samples were separated into straw and grains, dried at $70{ }^{\circ} \mathrm{C}$ for 72 hours, weighed, digested with concentration $\mathrm{H} 2 \mathrm{SO} 4 / \mathrm{HClO} 4$ and analyzed for total nitrogen, phosphorus and potassium (Chapman and Pratt 1961). Total nitrogen in plant was determined using the microkjeldahl method according to Chapman and Pratt (1961). Total potassium in plant was determined by flame photometer according to Chapman and Pratt (1961). Total phosphorus in plant was determined colourmetrically using ascorbic acid method (Watanabe and Olsen, 1965). Protein percent "yield quality" in grains was calculated by multi plying N\% $\times 5.70$ (Bishni and Hughes, 1979).

\section{Results and Discussion}

\section{Soil properties as affected by gypsum and compost}

Bulk density (BD) as affected by different amendments (i.e. gypsum and compost) is shown in Table 1. It is obvious from the data that BD is influenced by application of all tested treatments compared with initial soil. The minimum BD was recorded with compost followed by gypsum. Amendments application decreased to 1.35 and $1.39 \mathrm{Mg} . \mathrm{m}-3$ due to gypsum and compost compared with initial soil (having BD 1.45 Mg.m-3), respectively. Regarding to soil salinity, the residual total soluble salts in soil at end of the reclamation process, expressed as EC of the saturated soil extract, as shown in Table 1. The obtained data prove that EC in soil are influenced by application of all tested treatments. The initial soil salinity (having $15.63 \mathrm{dSm}-1$ ) was reduced to 3.65 and $5.51 \mathrm{dSm}-1$ for the different treatment of gypsum and compost, respectively. Regarding soil $\mathrm{pH}$, data indicated the application amendments caused an appreciated reduction in soil $\mathrm{pH}$ if compared with initial soil. The initial soil $\mathrm{pH}$ (having 7.89) was reduced to 
7.77 and 7.68 for gypsum and compost, respectively. Results showed a slightly lower in soil $\mathrm{pH}$ between treatments, this may be explained by soil must have had high buffering capacity due to the Clay texture. Sodium adsorption ratio (SAR) is a reliable index for testing the remediation efficiency of sodic soils. Data in Table 1 reveal that the initial SAR value was high and dropped sharply to 5.48 and 6.74 after the end of reclamation process for gypsum and compost, respectively. Regarding ESP, respective decreases were 7.90 and $13.55 \%$ for gypsum and compost, respectively.

TABLE 1. Physical and chemical properties of studied soil

\begin{tabular}{|c|c|c|c|}
\hline \multirow[b]{2}{*}{ Property } & \multicolumn{3}{|c|}{ Studied soil } \\
\hline & $\begin{array}{l}\text { Initial soil } \\
\text { before } \\
\text { reclamation } \\
\text { process }\end{array}$ & $\begin{array}{l}\text { After treated } \\
\text { by gypsum }\end{array}$ & $\begin{array}{l}\text { After treated by } \\
\text { compost }\end{array}$ \\
\hline Texture class & Clay & Clay & Clay \\
\hline Bulk density, Mg.m ${ }^{-3}$ & 1.45 & 1.39 & 1.35 \\
\hline Organic matter, $\mathrm{g} \mathrm{kg}^{-1}$ & 2.20 & 2.50 & 3.30 \\
\hline Saturation point, $\%$ & 32.25 & ------ & ------ \\
\hline EC, dS/m (soil paste extract) & 15.63 & 3.65 & 5.51 \\
\hline $\mathrm{pH}$ (soil suspension $1: 2.5)$ & 7.89 & 7.77 & 7.68 \\
\hline $\mathrm{Ca}^{2+}, \mathrm{mmol}_{\mathrm{C}} / \mathrm{L}$ & 12.59 & 16.33 & 12.33 \\
\hline $\mathrm{Mg}^{2+}, \mathrm{mmol}_{\mathrm{c}} / \mathrm{L}$ & 69.93 & 2.94 & 14.44 \\
\hline $\mathrm{Na}^{+}, \mathrm{mmol}_{\mathrm{c}} / \mathrm{L}$ & 63.33 & 14.79 & 24.65 \\
\hline $\mathrm{K}^{+}, \mathrm{mmol}_{\mathrm{c}} / \mathrm{L}$ & 10.45 & 2.44 & 3.68 \\
\hline $\mathrm{HCO}_{3}^{-}, \mathrm{mmol}_{\mathrm{c}} / \mathrm{L}$ & 61.96 & 14.47 & 21.84 \\
\hline $\mathrm{Cl}^{-}, \mathrm{mmol}_{\mathrm{C}} / \mathrm{L}$ & 35.63 & 8.32 & 12.56 \\
\hline $\mathrm{SO}_{4}={ }^{\prime}, \mathrm{mmol}_{\mathrm{c}} / \mathrm{L}$ & 58.71 & 13.70 & 20.70 \\
\hline SAR & 9.86 & 5.48 & 6.74 \\
\hline $\mathrm{CEC}, \mathrm{cmol}_{\mathrm{C}} / \mathrm{kg}$ soil & 25.45 & 25.45 & 25.45 \\
\hline ESP, $\%$ & 19.61 & 7.90 & 13.55 \\
\hline
\end{tabular}

Gypsum decreases the ratio of sodicity to salinity in percolating solutions and provides a relatively uniform hydraulic gradient throughout the soil profile (Miyamoto and Enriquez 1990). The application of gypsum followed by a mature municipal solid compost mix has been used to restore degraded sodic soils (Hanay et al., 2004). Similarly, Siyal et al. (2002) reported that gypsum was effective in the reclamation of sodic soils. The application of gypsum decreases the $\mathrm{pH}$, electrical conductivity (EC), exchangeable sodium percentage (ESP), and bulk density and increases the hydraulic conductivity and infiltration rate (AbdelFattah, 2011, 2012 and Abdel-Fattah et al., 2015). The addition of organic matter in conjunction with gypsum has been successful in reducing adverse soil properties associated with sodic soils. Addition of organic matter and gypsum to the surface soil will decrease spontaneous dispersion and EC down to the subsoil, compared to the addition of gypsum alone (Vance et al., 1998). 
TABLE 2. Physicochemical characteristics of botanical compost

\begin{tabular}{|l|c|}
\hline \multicolumn{1}{|c|}{ Characteristics } & Value \\
\hline Moisture, \% & 23.00 \\
$\mathrm{pH}$ & 6.87 \\
$\mathrm{EC}, \mathrm{dSm}^{-1}$ (Compost extract $\left.1: 10\right)$ & 4.57 \\
Total N, \% & 1.00 \\
$\mathrm{~N}_{\mathrm{NHH}}, \mathrm{ppm}$ & 67.00 \\
$\mathrm{~N}_{\mathrm{NO}}, \mathrm{ppm}$ & 17.00 \\
Organic matter, \% & 30.50 \\
Organic carbon, \% & 14.79 \\
Ash, $\%$ & 74.50 \\
$\mathrm{C} / \mathrm{N} \mathrm{Ratio}$ & $1: 14.79$ \\
Total P-P $\mathrm{O}_{5}, \%$ & 0.73 \\
Total K- $\mathrm{K}_{2} \mathrm{O}, \%$ & 1.03 \\
\hline
\end{tabular}

TABLE 3. The chemical composition of Moringa oleifera leave extract

\begin{tabular}{|l|c|}
\hline Characteristics & Values, $\mathbf{g} \mathbf{1 0 0} \mathbf{~ g}^{\mathbf{- 1}} \mathbf{d ~ w t}$ \\
\hline Protein & 27.30 \\
Phosphorus (P) & 0.39 \\
Potassium (K) & 0.11 \\
Calcium (Ca) & 2.40 \\
Magnesium (Mg) & 0.45 \\
Iron (Fe) (B-carotene) & 0.033 \\
Vitamin A ( $)$ & 0.02 \\
Vitamin B1(thiamine) & 0.0026 \\
Vitamin B2 (riboflavin) & 0.021 \\
Vitamin B3(nicotinic acid) & 0.008 \\
Vitamin C (ascorbic acid) & 0.017 \\
Vitamin E (tochopherol acetate) & 0.113 \\
\hline
\end{tabular}

TABLE 4. The chemical composition of marine algae extract

\begin{tabular}{|l|c|}
\hline Characteristics & Values, \% \\
\hline $\mathrm{N}$ & 1.33 \\
$\mathrm{P}$ & 0.46 \\
$\mathrm{~K}$ & 12.4 \\
$\mathrm{Ca}$ & 0.55 \\
$\mathrm{Mg}$ & 0.35 \\
$\mathrm{Fe}$ & 0.008 \\
Alginic acid & 5.60 \\
Cytokinine & 0.001 \\
indol acetic acid & 0.002 \\
Pepsin & 0.02 \\
Oligo saccharide & 3.50 \\
Phytin & 0.003 \\
\hline
\end{tabular}


Yield parameters, photosynthetic pigments and yield

Data presented in Table 5 show the effect of fulvic acid application and foliar sprays with moringa leaf extract and marine algae extracton growth yield parameters, yield and photosynthetic pigments of wheat plants grown under soils reclaimed with gypsum and compost. All the values of treatments significantly increased yield parameters and photosynthetic pigments (chlorophyll a, b and caroteniods) as compared to control (without application) under all the soils. The highest values of plant height, leaf area, straw and grain yield and photosynthetic pigments occurred with FA+MLE treatment followed by FA+MAE, MLE, MAE,FA, respectively and control in descending order in the two soils. These results are in agreement with those obtained by Celik et al.(2008).Fluvic acids influence on soil physical and chemical properties, and absorption of nutrients has increased by use of fluvic acids, leading to improved root growth and fresh and dry yield of plants. In many cases, fluvic compounds reduced required amount of fertilizers and improved soil conditions (Kao and Govindaraju, 2010).

TABLE 5. Effect of fulvic acid and foliar sprays of moringa leaf and marine algae extracts on yield and photosynthetic pigments of wheat plants under soils reclaimed with gypsum and compost

\begin{tabular}{|c|c|c|c|c|c|c|c|c|c|}
\hline \multirow{2}{*}{\multicolumn{2}{|c|}{ Factors of study effects }} & \multirow{2}{*}{$\begin{array}{c}\text { Plant } \\
\text { height } \\
\text { cm }\end{array}$} & \multirow{2}{*}{$\begin{array}{l}\text { Leaf } \\
\text { area } \\
\mathrm{cm}^{2}\end{array}$} & \multirow{2}{*}{$\begin{array}{c}\text { straw } \\
\text { yield } \\
\text { g plant }^{-1}\end{array}$} & \multirow{2}{*}{$\begin{array}{c}\text { grain } \\
\text { yield } \\
\text { g plant } \text { pla }^{-1}\end{array}$} & \multirow{2}{*}{$\begin{array}{l}\text { Bio. } \\
\text { yield g } \\
\text { plant }^{-1}\end{array}$} & \multicolumn{3}{|c|}{$\begin{array}{l}\text { Photosynthetic pigments } \\
\text { mg g }^{-1} \text { fresh weight }\end{array}$} \\
\hline & & & & & & & cho a & cho b & chrotein \\
\hline \multicolumn{10}{|c|}{ Amendment type effect } \\
\hline \multicolumn{2}{|c|}{$\overline{\text { Gypsum }}$} & 81.64 & 18.20 & 1.25 & 1.02 & 2.28 & 1.36 & 0.64 & 0.52 \\
\hline \multicolumn{2}{|l|}{ Compost } & 90.11 & 19.81 & 1.30 & 1.11 & 2.30 & 1.44 & 0.68 & 0.62 \\
\hline \multicolumn{2}{|c|}{ LSD $0.05 \%$} & 1.24 & 0.67 & 0.01 & 0.02 & Ns & 0.02 & 0.004 & 0.01 \\
\hline \multicolumn{10}{|c|}{ Foliar spray effect } \\
\hline \multicolumn{2}{|c|}{$\overline{\text { Without }}$} & 74.77 & 15.74 & 0.95 & 0.75 & 1.70 & 1.16 & 0.54 & 0.44 \\
\hline \multicolumn{2}{|l|}{ FA } & 78.38 & 17.59 & 1.27 & 0.90 & 2.10 & 1.26 & 0.59 & 0.49 \\
\hline \multicolumn{2}{|l|}{ MAE } & 82.93 & 18.96 & 1.31 & 1.00 & 2.25 & 1.34 & 0.64 & 0.56 \\
\hline \multicolumn{2}{|l|}{ MLE } & 86.35 & 19.84 & 1.34 & 1.13 & 2.41 & 1.44 & 0.68 & 0.60 \\
\hline \multicolumn{2}{|l|}{$\mathrm{FA}+\mathrm{MAE}$} & 92.83 & 20.80 & 1.37 & 1.23 & 2.54 & 1.56 & 0.73 & 0.65 \\
\hline \multicolumn{2}{|l|}{$\mathrm{FA}+\mathrm{MLE}$} & 99.97 & 21.12 & 1.43 & 1.39 & 2.71 & 1.67 & 0.77 & 0.67 \\
\hline \multicolumn{2}{|c|}{ LSD $0.05 \%$} & 2.14 & 1.16 & 0.02 & 0.04 & 0.05 & 0.03 & 0.01 & 0.02 \\
\hline \multicolumn{10}{|c|}{ Interaction effect } \\
\hline \multirow[t]{6}{*}{ Gypsum } & Without & 71.17 & 14.77 & 0.92 & 0.72 & 1.65 & 1.12 & 0.52 & 0.40 \\
\hline & FA & 75.43 & 17.20 & 1.25 & 0.87 & 2.12 & 1.23 & 0.56 & 0.44 \\
\hline & MAE & 78.30 & 18.56 & 1.29 & 0.94 & 2.23 & 1.33 & 0.62 & 0.50 \\
\hline & MLE & 81.73 & 19.01 & 1.32 & 1.10 & 2.42 & 1.42 & 0.66 & 0.54 \\
\hline & $\mathrm{FA}+\mathrm{MAE}$ & 87.80 & 20.11 & 1.35 & 1.20 & 2.55 & 1.49 & 0.72 & 0.62 \\
\hline & FA+MLE & 95.38 & 19.54 & 1.39 & 1.31 & 2.70 & 1.60 & 0.75 & 0.64 \\
\hline \multirow[t]{6}{*}{ Compost } & Without & 78.37 & 16.71 & 0.97 & 0.79 & 1.76 & 1.20 & 0.56 & 0.48 \\
\hline & FA & 81.33 & 17.97 & 1.29 & 0.93 & 2.08 & 1.28 & 0.62 & 0.54 \\
\hline & MAE & 87.57 & 19.37 & 1.33 & 1.05 & 2.26 & 1.34 & 0.66 & 0.62 \\
\hline & MLE & 90.97 & 20.67 & 1.36 & 1.15 & 2.41 & 1.46 & 0.69 & 0.66 \\
\hline & $\mathrm{FA}+\mathrm{MAE}$ & 97.87 & 21.48 & 1.39 & 1.25 & 2.54 & 1.63 & 0.75 & 0.69 \\
\hline & FA+MLE & 104.57 & 22.69 & 1.48 & 1.46 & 2.73 & 1.74 & 0.79 & 0.70 \\
\hline \multicolumn{2}{|l|}{ LSD $0.05 \%$} & Ns & Ns & $\mathrm{Ns}$ & Ns & Ns & 0.04 & 0.01 & 0.02 \\
\hline
\end{tabular}

FA: fulvic acid, MAE: marine algae extract, MLE: moringa leaf extract, cho a: chlorophyll a, cho b: chlorophyll b

Egypt. J. Soil Sci. 56, No. 4(2016) 
From statistical analysis, results showed that the foliar spray with moringa leaf extract gave a significant increase in growth yield parameters, dry weight of straw and grain and photosynthetic pigments compared to foliar spray with marine algae extract in the two soils. This result confirmed by Merwad (2015). The aqueous extracts of leaf and twigs of moringa oleifera were foliar sprayed onto rocket plants at rates of 1,2 and $3 \%$. Among these concentrations, fertilizations of rocket plants with $2 \%$ leaf and $3 \%$ twig extracts potentially increased all measured growth criteria (plant height, fresh and herb weight), chlorophyll a and b, total sugars , ascorbic acid, phenols (Abdalla, 2013).

Application of fluvic acid positively affected plant growth under saline soil conditions, but higher doses of FA inhibited plant growth (Türkmen et al., 2004). Young suggested that fluvic materials can affect physiological processes of plant growth directly or indirectly (Yang et al., 2004). Fluvic substances might show anti-stress effects under abiotic stress conditions such as, unfavorable temperature, $\mathrm{pH}$, salinity etc. Fluvic substances could improve plant growth under soil condition with enhancing the uptake of nutrients and reducing the uptake of some toxic elements (Kulikova et al., 2005).

\section{Nutrients uptake}

Data presented in Table 6 show the effect of fulvic acid application and foliar sprays with moringa leaf extract and marine algae extract on straw and grain $\mathrm{N}, \mathrm{P}$ and $\mathrm{K}$ uptake of wheat plants grown under soils reclaimed with gypsum and compost. All the values of treatments significantly increased NPK uptake as compared to control under all the soils. The highest values of straw and grain NPK-uptake were obtained with FA combined with moringa extract spray. However, non-treated plants showed the lowest NPK- uptake. Treatments could be arranged in the following order regarding the main effects FA+ MLE> FA+MAE $>$ MLE $>$ MAE $>$ FA $>$ without under different soils. Several studies have shown that fluvic substances can have a positive effect on plant growth (Arancon et al., 2006). Under salt stress, the lowest doses of both soil and foliar application of fluvic substances increased the nutrient uptake of wheat (Asik et al., 2009). Different part of Moringa oleifera plants have been reported to be a rich source of important minerals as $\mathrm{Ca}, \mathrm{Mg}, \mathrm{K}, \mathrm{P}, \mathrm{S}, \mathrm{Cu}, \mathrm{Zn}, \mathrm{Mn}$ and $\mathrm{Fe}$ which can be valorized for a balanced nutrition of population (Yameogo et al., 2011 and Moyo et al., 2011).

Regarding the mean effect of using soil amendments in reclaimed soils, the data show that soils reclaimed with compost gave higher values of straw and grains NPK- uptake than the values under application of gypsum under different treatments. This result could be due to the high nutrient content and the low $\mathrm{C} / \mathrm{N}$ rates in compost. This result is in agreement with that obtained by Palm et al., (2001). Positive effects of organic waste on soil structure, aggregate stability and water-holding capacity were reported in several studies (Odlare et al., 2008).Soil physical properties were improved after municipal solid waste compost addition. In medium and high doses, augmentations in organic matter reduced bulk density and enhanced water infiltration (Civeira, 2010).

Egypt. J. Soil Sci. 56, No. 4 (2016) 
TABLE 6. Effect of fulvic acid and foliar sprays of moringa leaf and marine algae extracts on straw and grain NPK-uptake of wheat plants under soils reclaimed with gypsum and compost

\begin{tabular}{|c|c|c|c|c|c|c|c|}
\hline \multirow{2}{*}{\multicolumn{2}{|c|}{ Factors of study effects }} & \multicolumn{3}{|c|}{ Straw } & \multicolumn{3}{|c|}{ Grain } \\
\hline & & $\begin{array}{c}\text { N- } \\
\text { uptake }\end{array}$ & $\begin{array}{c}\text { P- } \\
\text { uptake }\end{array}$ & $\begin{array}{c}\text { K- } \\
\text { uptake }\end{array}$ & $\begin{array}{c}\text { N- } \\
\text { uptake }\end{array}$ & $\begin{array}{c}\text { P- } \\
\text { uptake }\end{array}$ & $\begin{array}{c}\text { K- } \\
\text { uptake }\end{array}$ \\
\hline \multicolumn{8}{|c|}{ Amendment type effect } \\
\hline \multicolumn{2}{|c|}{ Gypsum } & 15.23 & 3.02 & 17.06 & 14.08 & 2.89 & 13.28 \\
\hline \multicolumn{2}{|l|}{ Compost } & 17.65 & 3.81 & 19.03 & 16.02 & 3.95 & 15.57 \\
\hline \multicolumn{2}{|c|}{ LSD $0.05 \%$} & 0.35 & 0.11 & 0.39 & 0.41 & 0.15 & 0.45 \\
\hline \multicolumn{8}{|c|}{ Foliar spray effect } \\
\hline \multicolumn{2}{|c|}{ Without } & 8.68 & 1.47 & 11.29 & 7.56 & 1.38 & 8.29 \\
\hline \multicolumn{2}{|l|}{ FA } & 13.72 & 2.53 & 16.20 & 10.65 & 2.03 & 10.93 \\
\hline \multicolumn{2}{|l|}{ MAE } & 16.04 & 3.18 & 17.50 & 13.13 & 2.81 & 12.87 \\
\hline \multicolumn{2}{|l|}{ MLE } & 17.77 & 3.65 & 18.88 & 16.23 & 3.60 & 15.47 \\
\hline \multicolumn{2}{|l|}{$\mathrm{FA}+\mathrm{MAE}$} & 19.78 & 4.34 & 20.63 & 19.20 & 4.53 & 17.49 \\
\hline \multicolumn{2}{|l|}{$\mathrm{FA}+\mathrm{MLE}$} & 22.63 & 5.34 & 23.75 & 23.56 & 6.17 & 21.50 \\
\hline \multicolumn{2}{|l|}{ LSD $0.05 \%$} & 0.60 & 0.19 & 0.67 & 0.71 & 0.27 & 0.78 \\
\hline \multicolumn{8}{|c|}{ Interaction effect } \\
\hline \multirow[t]{6}{*}{ Gypsum } & Without & 7.92 & 1.23 & 10.71 & 6.75 & 1.21 & 7.33 \\
\hline & FA & 12.00 & 2.25 & 15.25 & 9.71 & 1.71 & 10.23 \\
\hline & MAE & 15.01 & 2.71 & 16.55 & 12.29 & 2.30 & 11.57 \\
\hline & MLE & 16.76 & 3.31 & 18.04 & 15.72 & 3.04 & 14.67 \\
\hline & $\mathrm{FA}+\mathrm{MAE}$ & 18.77 & 3.86 & 19.49 & 18.32 & 3.88 & 16.48 \\
\hline & $\mathrm{FA}+\mathrm{MLE}$ & 20.90 & 4.77 & 22.29 & 21.69 & 5.23 & 19.38 \\
\hline \multirow[t]{6}{*}{ Compost } & Without & 9.44 & 1.72 & 11.87 & 8.36 & 1.54 & 9.25 \\
\hline & FA & 15.43 & 2.80 & 17.16 & 11.60 & 2.36 & 11.63 \\
\hline & MAE & 17.07 & 3.65 & 18.44 & 13.96 & 3.32 & 14.17 \\
\hline & MLE & 18.77 & 3.99 & 19.72 & 16.74 & 4.15 & 16.27 \\
\hline & $\mathrm{FA}+\mathrm{MAE}$ & 20.80 & 4.81 & 21.77 & 20.07 & 5.19 & 18.49 \\
\hline & $\mathrm{FA}+\mathrm{MLE}$ & 24.37 & 5.91 & 25.22 & 25.42 & 7.12 & 23.63 \\
\hline LSD $0.05 \%$ & & 0.86 & 0.27 & Ns & 1.00 & 0.38 & 1.10 \\
\hline
\end{tabular}

Yield quality and weight of 1000 grains

Data presented in Table 7 show the effect of fulvic acid application and foliar sprays with moringa leaf extract and marine algae extract on weight of 1000 grains, protein content and harvest index of wheat plants grown under soils reclaimed with gypsum and compost. All the values of treatments significantly increased weight of 1000 grains and yield quality as compared to control under all the soils. Also, the highest percentage increase in 1000 grains, protein content and harvest index of $25.81,77.81$ and $10.31 \%$, respectively were recorded from the treatment of FA+MLE under soil reclaimed with gypsum. On the other hand, the highest percentage increase in 1000 grains, protein content and harvest index of $26.13,63.36$ and $19.96 \%$, respectively was recorded from the same treatment under soil reclaimed with compost.These results are agreement with those obtained by Türkmen et al. (2004).

From statistical analysis, results showed that the foliar spray with moringa leaf extract gave a significant increase in protein content and harvest index compared to foliar spray with marine algae extract in the two soils. Consistent results were obtained by Culver et al. (2013). Moringa leaf has been purported to be a good source of nutrition and a naturally organic health supplement that used in many therapeutic ways (McBurney et al., 2004; Fahey, 2005; DanMalam et al., 2001). Foidl et al. (2001) reported that foliar spraying of some plant leaves with moringa extract produced some notable effects as overall increase in plant yield between 20 and $35 \%$ and higher sugar and mineral levels.

Egypt. J. Soil Sci. 56, No. 4(2016) 
TABLE 7. Effect of fulvic acid and foliar sprays of moringa leaf and marine algae extracts on weight1000 grain, protein and harvest index of wheat plants under soils reclaimed with gypsum and compost

\begin{tabular}{|c|c|c|c|c|}
\hline \multicolumn{2}{|c|}{ Factors of study effects } & $\begin{array}{l}\text { Weight of } \\
1000 \text { grain }\end{array}$ & protein & harvest index \\
\hline \multicolumn{5}{|c|}{ Amendment type effect } \\
\hline \multicolumn{2}{|c|}{ Gypsum } & 49.51 & 7.57 & 44.68 \\
\hline \multicolumn{2}{|c|}{ Compost } & 51.75 & 8.01 & 47.75 \\
\hline \multicolumn{2}{|c|}{ LSD $0.05 \%$} & 0.69 & 0.09 & 0.66 \\
\hline \multicolumn{5}{|c|}{ Foliar spray effect } \\
\hline \multicolumn{2}{|c|}{ Without } & 45.75 & 5.69 & 44.30 \\
\hline \multicolumn{2}{|l|}{ FA } & 47.03 & 6.74 & 42.88 \\
\hline \multicolumn{2}{|l|}{ MAE } & 48.12 & 7.51 & 44.23 \\
\hline \multicolumn{2}{|l|}{ MLE } & 50.57 & 8.22 & 46.60 \\
\hline \multicolumn{2}{|l|}{$\mathrm{FA}+\mathrm{MAE}$} & 54.69 & 8.91 & 48.23 \\
\hline \multicolumn{2}{|c|}{ FA+MLE } & 57.63 & 9.68 & 51.03 \\
\hline \multicolumn{2}{|c|}{ LSD $0.05 \%$} & 1.20 & 0.16 & 1.14 \\
\hline \multicolumn{5}{|c|}{ Interaction effect } \\
\hline \multirow[t]{6}{*}{ Gypsum } & Without & 44.89 & 5.32 & 43.93 \\
\hline & FA & 46.55 & 6.37 & 41.02 \\
\hline & MAE & 47.46 & 7.43 & 42.24 \\
\hline & MLE & 48.90 & 8.17 & 45.29 \\
\hline & $\mathrm{FA}+\mathrm{MAE}$ & 52.77 & 8.70 & 47.12 \\
\hline & FA+MLE & 56.48 & 9.46 & 48.46 \\
\hline \multirow[t]{6}{*}{ Compost } & Without & 46.60 & 6.06 & 44.68 \\
\hline & FA & 47.51 & 7.11 & 44.73 \\
\hline & MAE & 48.78 & 7.60 & 46.23 \\
\hline & MLE & 52.23 & 8.27 & 47.91 \\
\hline & $\mathrm{FA}+\mathrm{MAE}$ & 56.62 & 9.12 & 49.33 \\
\hline & FA+MLE & 58.78 & 9.90 & 53.60 \\
\hline \multicolumn{2}{|c|}{ LSD $0.05 \%$} & $\mathrm{Ns}$ & 0.23 & 1.61 \\
\hline
\end{tabular}

FA: fulvic acid, MAE: marine algae extract, MLE: moringa leaf extract

\section{Conclusion}

A pot experiment was conducted under the greenhouse conditions at the Farm of the Faculty of Agriculture Zagazig University to try reclamation and cultivation of saline-sodic soils. Soil materials were collected from Sahl El-Tin, Sinai Governorate, Egypt. After reclamation process, the same pots were planted with wheat to study the effect of fulvic acid as soil application and foliar sprays with Moringa leaf extract and Marine algae extract as Ascophyllum nodosum onphotosynthetic pigments, yield and nutrient uptake of wheat (Triticum aestivum cv., Sakha 93) under newly reclaimed soils with gypsum and compost. The results of the study indicated that gypsum and compost showed a pronounced decreased in bulk density, EC, pH, SAR and ESP compared with the initial soil with superiority of gypsum on compost in reducing EC, SAR and ESP.The highest values of plant height, leaf area, chlorophyll a, b and caroteniods, yield, straw and grain NPK-uptake, 1000 grain weight and protein content were obtained with FA combined with moringa extract spray. However, 
non-treated plants showed the lowest one. Spraying with moringa leaf extract gave a significant increase in growth yield parameters; yield, photosynthetic pigments, NPK-uptake, 1000 grain weight and protein content compared to foliar spray with marine algae extract in the two soils. Soils reclaimed with compost gave higher values of yield, straw and grains NPK- uptake and protein content than the values under application of gypsum under different treatments.

\section{References}

Abdalla, M. A. (2013) The potential of Moringa oleifera extract as a biostimulant in enhancing the growth, biochemical and hormonal cntents in rocket (Eruca versicaria subsp. Sativa) plants. Int. J . Plant Physiol. Biochem. 5(3), pp. 42-49.

Abdel-Fattah, M. K. (2011) Some biological and chemical methods for salt-affected soils reclamation. PhD thesis, Faculty of Agriculture, Zagazig University, Zagazig, Egypt.

Abdel-Fattah, M. K. (2012) Role of gypsum and compost in reclaiming saline-sodic soils. IOSR Journal of Agriculture and Veterinary Science (IOSR-JAVS), 1(3), 30-38.

Abdel-Fattah, M. K., Fouda, S. and schmidhalte, U. (2015) Effects of Gypsum Particle Size on Reclaiming Saline-Sodic Soils in Egypt. Communications in Soil Science and Plant Analysis, 46(9),1112-1122, 2015. DOI: $10.1080 / 00103624.2015 .1018528$.

Abdel-Moaz, M.R. and Saleh, A.l. (1999) Effect of organic fertilizers application on growth, yield and mineral uptake of Roselle-plants as compared to chemical fertilizer. J. Agric. Sci., Mansoura Univ., 24, 3157-3163.

Arancon, N.Q., Edwards, C.A. Lee, S. and Byrne, R. (2006) Effects of humic acids from vermicomposts on plant growth. Soil Bio., 42, 565-569.

Asik, B. B., Turan, M. A.. Celik, H. and Katkat, A. V. (2009) Effect of humic substances to dry weight and mineral nutrients uptake of wheat on saline soil conditions. Asian J. crops Sci., 1, 87-95.

Beckett, R.P. and van Staden, J. (1990) The effect of seaweed concentrate on the yield of nutrient stressed wheat. Bot Mar 33,147-152.

Beckett, R.P., Mathegka, A.D.M. and Van Staden, J. (1994) Effect of seaweed concentrate on yield of nutrient-stressed tepary bean (Phaseolus acutifolius Gray). J Appl Phycol 6, 429-430.

Bishni, U.R. and Hughes, I. L. (1979) Agronomic performance and protein content of fall -planted tritica, wheat and rye. Agron.J.,71, 359-360.

Çelik, H., Katkat, A.V., Aýk, B. B. and Turan, M. A. (2008) Effects of soil application of humus on dry weight and mineral nutrients uptake of maize under calcareous soil conditions. Archives of Agron. Soil Sci., 54, 605-614.

Chapman, D.H. and Pratt P.F. (1961) "Methods of analysis for soil, plant and waters" .California. Univ.; Division of Agric. Sci.

Egypt. J. Soil Sci. 56, No. 4(2016) 
Chhabra, R. (1996) Soil Salinity and Water Quality. J. Irrigation and Drainage Systems . 11 (3), 281-282.

Civeira, G. (2010) Influence of municipal solid waste compost on soil properties and plant reestablishment in peri-urban environments. Chil. J. Agric. Res., 70, 446-453.

Culver,M., Tagwira, F. and Chiteka, A.Z. (2013) Effect of moringa extract on growth and yield of maize and common Beans. Greener J. Agric. Sci. 3(1), 55-62.

DanMalam, H. U., Abubakar, Z. and Katsayal, U. A. (2001) Pharmacognostic studies on the leaves of Moringa oleifera. Nigerian Journal of Natural Product and Medicine 5,45-49.

Dillard, C.J. and German, J.B. (2000) "Phytochemicals: Nutraceuticals and Human Health". Journal of the Science of Food Agriculture. 80,1744-1756.

Fahey, J.W. (2005) Moringa Oleifera: A Review of the Medical Evidence for Its Nutritional,Therapeutic, and Prophylactic properties.Part 1. Trees for Life Journal, 1,5 .

Fike, J.H., Allen, V.G. Schmidt, R.E., Zhang, X., Fontenot, J.P., Bagley, C.P., Ivy, R.L., Evans, R.R., Coelho, R.W. and Wester, D.B. (2001) Tasco-Forage: I. Influence of a seaweed extract on antioxidant activity in tall fescue and in ruminants. $J$ Anim Sci 79,1011-1021.

Foidl, N., Makkar, H.P. and Becker, K. (2001) The potential of Moringa oleifera for agricultural and industrial uses. In: Proceedings of International Workshop"What development potential for Moringa product" Dares -Salaam, Tanzania. pp.47 - 67.

Fuglie, L. (2000) The Miracle Tree : Moringa oleifera: Natural Nutrition for the Tropics. The multiple Attributes of Moringa, pp.172.

Hanay, A., Büyüksönmez, F., Kiziloglu, F. M. and Canbolat, M. Y. (2004) Reclamation of saline sodic soils with gypsum and MSW compost. Compost Science and Utilization 12: 175-179. doi:10.1080/1065657X.2004.10702177.

Jifon, J. L. and Lester, G. E. (2009) Foliar potassium fertilization improves fruit quality of field-grown muskmelon on calcareous soils in south Texas. J. Sci. Food Agric. 89, $2452-2460$.

Kao, S. and Govindaraju, R.S. (2010) A copula-based joint deficit index for droughts. Hydrology J., 380,121-134.

Khan, W., Hiltz, D., Critchley, A.T. and Prithiviraj, B. (2011) Bioassay to detect Ascophyllum nodosum extract-induced cytokinin-like activity in Arabidopsis thaliana. J. Appl Phycol 23, 409-414.

Khan, W., Zhai, R., Souleimanov, A., Critchley, A. T., Smith, D. L. and Prithiviraj, B. (2012) A commercial extract of Ascophyllum nodosum improves root colonization of alfalfa by its bacterial symbiont Sinorhizobium meliloti. Comm. Soil Sci. Plant Anal. 43, 1-12. 
Khan, W., Rayirath, U. P., Subramanian, S., Jithesh, M. N., Rayorath, P., Hodges, D. M. Critchley, A. T., Craigie, J. S., Norrie, J. and Prithiviraj, B. (2009) Seaweed Extracts as Biostimulants of Plant Growth and Development. J. Plant Growth Regul. 28, 386-399.

Kulikova, N.A., Stepanova, E.V. and Koroleva, O.V. (2005) Mitigating activity of humic substances: Direct influence on biota. In: Use of humic substances to remediate polluted environments: From theory to practice (Ed.: I.U. Perminova). NATO Science Series IV. Earth and Environmental Series. Kluwer Academic Publishers, 285-309.

Kumar, K. and Goh, K. M. (2000) Crop residues and management practices: effects on soil quality, soil nitrogen dynamics crop yield, and nitrogen recovery. Adv. Agron., 68,197-319.

Makkar, H.P.S. and Becker, K. (1996) Nutritional value and antinutritional components of whole and ethanol extracted of Moringa oleifera leaves. Anim. Feed Sci. Technol. 63, 211-228.

Mashali, A.M. (1991) "Salinization, Land Reclamation and Management in the Near East". In the Application of Remote Sensing to Sustainable Agricultural Development. Con. Cairo 24-25 Nov. 1999.pp 37-45.

McBurney, R. P. H., Griffin, C. Paul, A. A. and Greenberg, D.C. (2004) The nutritional composition of African wild food plants: from compilation to utilization. Journal of Food Composition and Analysis.17, 277-289.

Merwad, A.M.A. (2015) Effect of moringa oleifera extracts on the growth, yield and nutrient uptake of spinach (Spinacia Oleracea L.). Greener J. Soil Science and Plant Nutrition. 2 (1), 16-22.

Metzner, H., Rau, H. and Senger, H. (1965) Unter suchungen zur synchronisier barkeit ein zeiner pigment. Mangol Mutanten von Chlorella plants. 65 186-191.

Miyamoto, S. and Enriquez, C. A. (1990) Comparative effects of chemical amendments on salt and $\mathrm{Na}$ leaching. Irrigation Science 11, 83-92. doi:10.1007/BF00188444.

Mooney, P.A. and van Staden, J. (1985) Effect of seaweed concentrate on the growth ofwheat under conditions of water stress. SAfr J Science 81, 632-633.

Moyo, B., Masika, P.J., Hugo, A. and Muchenje, V. (2011) Nutritional characterization of Moringa (Moringa oleifera Lam) leaves. Afr. J. Biotechnol.10(60), $12925-12933$

Nelson, W.R. and van Staden, J. (1986) Effect of seaweed concentrate on the growth of wheat. S Afr J Science 82,199-200.

Noctor, G. and Foyer, C. H. (1998) Ascorbate and glutathione: keeping active oxygen under control. Annu Rev Plant Physiol. Plant Mol Biol 49, 249-279. 
Odlare, M., Pell, M. and Svensson, K. (2008) Changes in soil chemical and microbiological properties during 4 years of application of various organic residues. Waste Manag., 28, 1246-1253.

Palm, C. A., Giller, K. E., Mafongoya, P.L. and Swift, M. J. (2001) Management of organic matter in the tropics: translating theory into practice. Nutr. Cycle Agro. Ecosystem, 61, 63-75.

Papenfus, H.B., Kulkarni, M.G., Stirk, W.A., Finnie J.F. and Van Staden, J. (2013) Effect of a commercial seaweed extract (kelpak) and polyamines on nutrient-deprived (N, P and K) okra seedlings. Sci Hort 151,142-146.

Priya, B. N. V., K. Mahavishnan , D. S.Gurumurthy , H. Bindumadhava, A. P. Upadhyaya and N.K. Sharmaa (2014): Fulvic Acid (FA) for enhanced nutrient uptake and growth: Insights from biochemical and genomic studies. Journal of Crop Improvement, 28, 6, 740-757.

Priya, V. N. V., H. Bindumadhava, K. Mahavishnan, A. P. Upadhyay, and N. Sharma (2011) Effect of fulvic acid in improving carbon $\left({ }^{14} \mathrm{C}\right)$ uptake and translocation in tobacco. J. Plant Biol. 38, 67-70.

Shangguan, Z.P., Shao, M.A. and Dyckmans, J. (2000) Nitrogen nutrition and water stress on leaf photosynthetic gas exchange and water use efficiency in winter wheat. Environ Exp Bot 44,141-149.

Siddhuraju, P. and Becker, K. (2003) Antioxidant properties of various solvent extracts of total phenolic constituents from three different agro-climatic origins of drumstick tree (Moring a oleiferalam). J. Agric.Food Chem.15, 2144-2155.

Siyal, A. A., Siyal, A. G. and Abro, Z. A. (2002) Salt-affected soils: Their identification and reclamation. Pakistan Journal of Applied Science 2, 537-40.

Türkmen, O., Dursun, A. ,Turan, M. and Erdinc, C. (2004) Calcium and humic acid affect seed germination, growth and nutrient content of tomato (Lycopersicon esculentum L.) seedlings under saline soil conditions. Acta Horticul. Scandinavica B., 54, 168-174.

USDA (1954) Diagnosis and improvement of saline and alkali soils. (Agriculture Hand Book No. 60 US Gov. Printing Office, Washington, 1954.

Vance, W. H., Tisdell, J. M. and McKenzie, B. M. (1998) Residual effects of surface application of organic matter and calcium salts on the subsoil of a red brown earth. Australian Journal of Experimental Agriculture, 38, 1998, 595-600.

Watanabe, F. S. and Olsen, S. R. (1965) Test of an ascorbic acid method for determining $\mathrm{P}$ in water and sodium bicarbonate extracts from soil. Soil Sci. Soc. Amer Proc. 29, 677-678.

Yameogo, C.W., Bengaly, M. D., Savadogo, A., Nikiema, P.A. and Traore, S.A. (2011) Determination of chemical composition and nutritional values of Moringa oleifera leaves. Pak. J. Nutr. 10(3), 264-268. 
Yang, C.M., Wang, M.H., Lu, Y.F., Chang, I.F. and Chou, C.H. (2004) Humic substances affect the activity of chlorophyllase. Chem. Ecol. J., 30, 1057-1065.

Zhang, X. and Eirvin, E. H. (2004) Cytokinin-containing seaweed and humic acid extracts associated with creeping bentgrass leaf cytokinins and drought resistance. Crop Science 44, 1737-1745.

\section{اتجاه لاستصلاح وتحسين خصوبة الأراضي المتأثرة بالأملاح}

كحمد كمال عبد الفتاح كحم ـعبد الرحمن محمد أمين مرواد قسم علوم الأراضي - كلية الزراعة - جامعة الزقازيق

أقيمت تجربة أصص تحت ظروف الصوبة بمزرعة كلية الزر اعة جامعة الزقازيق الأقاريق

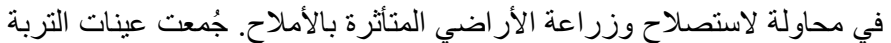

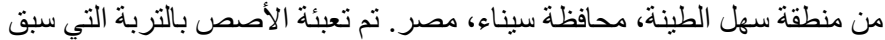

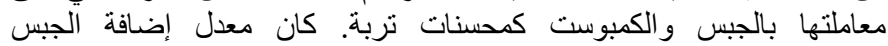

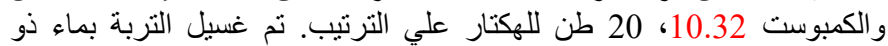

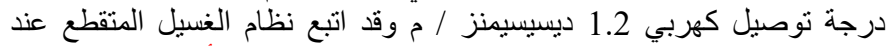

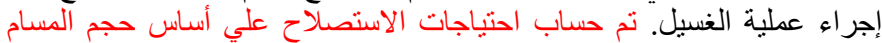
Pore Volume (PV)

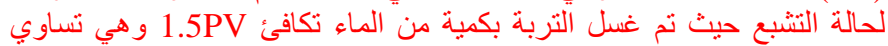

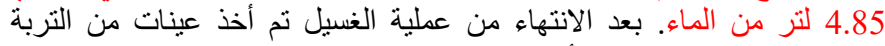

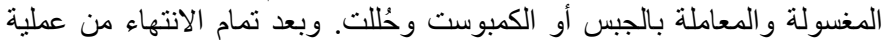

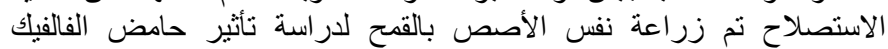

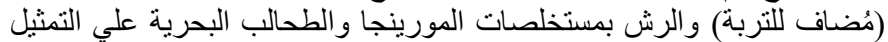

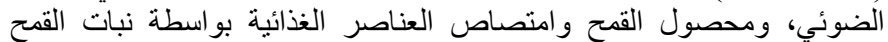

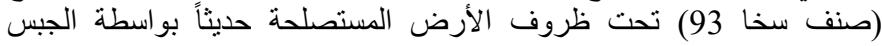
والكمبوست.

أظهرت نتائج التجربة أن الجبس و الكمبوست كمحسنات تربة لهما تأثثير واضح الكربح

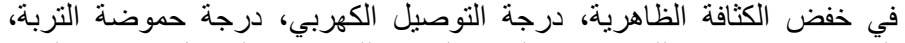

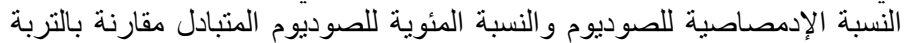

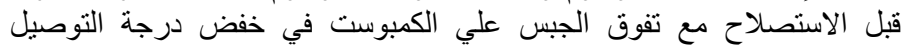

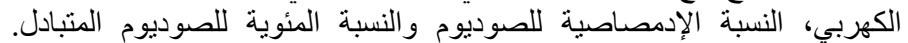

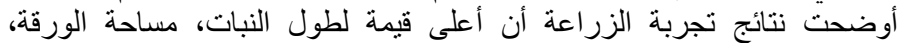

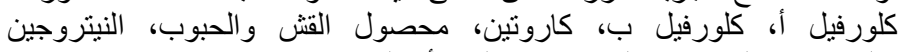

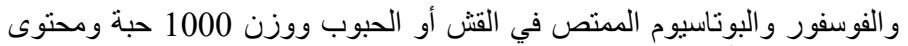

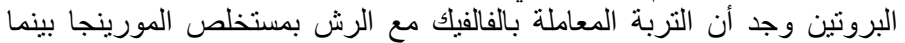

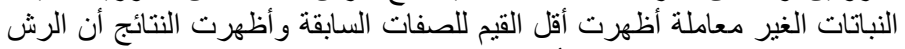

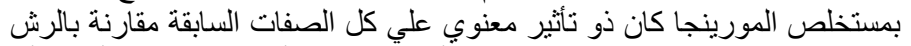

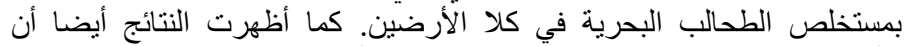

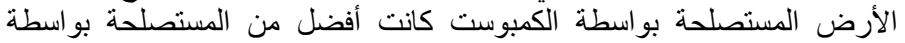

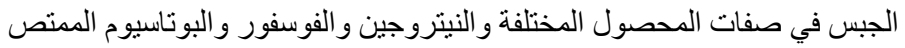

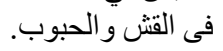

Egypt. J. Soil Sci. 56, No. 4(2016) 
